\title{
PELAKSANAAN REHABILITASI BAGI PECANDU NARKOTIKA PASCA BERLAKUNYA PERATURAN BERSAMA 7 (TUJUH) LEMBAGA NEGARA REPUBLIK INDONESIA*
}

\author{
Dani Krisnawati** dan Niken Subekti Budi Utami ${ }^{* * *}$ \\ Bagian Hukum Pidana, Fakultas Hukum Universitas Gadjah Mada, Yogyakarta \\ Jalan Sosio Yustisia Nomor 1 Bulaksumur, Sleman, D.I. Yogyakarta 55281
}

\begin{abstract}
This study is a normative-empirical research that use secondary and primary data. In the case of a voluntary reporting to the Sleman Police Precinct investigator by the drug addicts, the case will be coordinated to the medical and/or social rehabilitation agency, in this case is PSPP. However, after the implementation of Joint Regulation, no drug addicts voluntarily reported themselves. Whenever the suspects of the drug addiction that were caught, the Sleman Police Precinct investigator which is the element of law enforcement team beside the Sleman Narcotics National Agency, Sleman District Attorney, and Regional Office of the Ministry of Law and Human Rights Yogyakarta Province, coordinate themselves as a part of a joint assessment team, including with the Bhayangkara Hospital and Grhasia Hospital which serve as the medical doctor team.
\end{abstract}

Keywords: rehabilitation, drug addicts, investigators.

\section{Intisari}

Penelitian ini merupakan penelitian normatif empiris yang mengolah data primer dan sekunder. Hasil penelitian menunjukkan bahwa tindakan penyidik pasca berlakunya Peraturan Bersama terhadap pecandu yang secara sukarela melaporkan diri ke penyidik Polres Sleman, akan dikoordinasikan ke lembaga medis dan/atau sosial, dalam hal ini Panti Sosial Pamardi Putra. Meskipun pasca berlakunya Peraturan Bersama belum ada pecandu yang secara sukarela melaporkan diri, sedangkan bagi tersangka pecandu narkotika yang ditangkap, penyidik Polres Sleman saling berkoordinasi dengan tim hukum yang lain sebagai bagian dari tim assessment terpadu dan tim dokter dari Rumah Sakit Bhayangkara dan Rumah Sakit Grhasia yang merupakan bagian dari tim dokter.

Kata Kunci: rehabilitasi, pecandu narkotika, penyidik.

\section{Pokok Muatan}

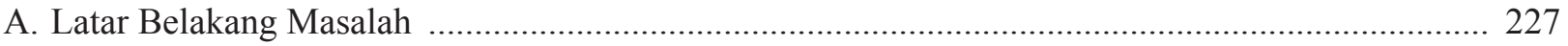

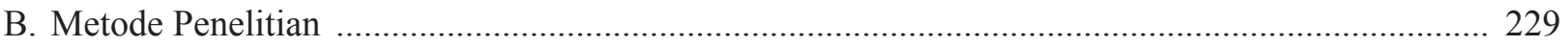

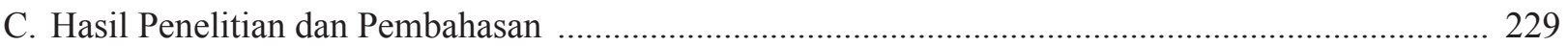

1. Tindakan Penyidik terhadap Pecandu Narkotika Pasca Berlakunya Peraturan Bersama ........... 229

2. Koordinasi antara Penyidik dengan Lembaga Rehabilitasi Medis dan Rehabilitasi Sosial terhadap Pecandu Parkotika Pasca Berlakunya Peraturan Bersama ............................................ 233

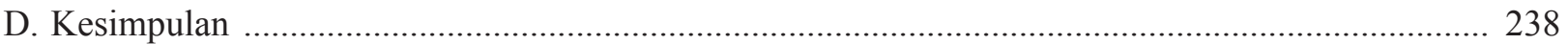

Hibah penelitian dari Unit Penelitian dan Pengabdian pada Masyarakat, Fakultas Hukum UGM, Tahun 2014.

Alamat korespondensi: danikrisnowoati@gmail.com

****Alamat korespondensi: niken.subekti@mail.ugm.ac.id 


\section{A. Latar Belakang Masalah}

Dalam rangka mewujudkan Indonesia negeri bebas narkoba, Badan Narkotika Nasional dan selanjutnya disingkat BNN mencanangkan tahun 2014 sebagai tahun penyelamatan penyalahgunaan narkoba. Hal ini dilakukan sebagai langkah antisipasi untuk menekan jumlah penyalahgunaan narkoba, mengingat setiap tahunnya jumlah penyalahgunaan narkoba cenderung terus meningkat. Pada saat ini jumlah penyalahgunaan narkoba di Indonesia sudah mencapai 4,2 juta jiwa. ${ }^{1}$ Untuk itu perlu langkah konkrit dalam menekan jumlah penyalahgunaan narkoba.

Sebenarnya upaya dalam menyelesaikan permasalahan narkoba sudah dilakukan secara lintas sektoral baik dari aspek preventif maupun represif dengan adanya peraturan perundang-undangan yang berkaitan dengan narkotika. Secara khusus upaya preventif telah dilakukan misalnya oleh aparat yang berkepentingan khususnya dari BNN, Kepolisian Republik Indonesia selanjutnya disingkat Polri dan Pejabat Pegawai Negeri Sipil selanjutnya disingkat PPNS maupun melalui partisipasi aktif masyarakat yaitu dengan munculnya lembaga-lembaga yang didirikan oleh masyarakat termasuk masyarakat kampus, ${ }^{2}$ yang peduli akan bahaya narkoba. Sedangkan upaya represif telah dilakukan mulai dari penangkapan sampai dengan proses hukum di pengadilan. Akan tetapi sampai saat ini jumlah penyalahgunaan narkoba belum berkurang bahkan cenderung bertambah.

Ketentuan sanksi yang diatur dalam UndangUndang Nomor 35 Tahun 2009 tentang Narkotika menganut double track system yaitu berupa sanksi pidana dan sanksi tindakan. Rehabilitasi merupakan salah satu bentuk sanksi tindakan. Namun berdasar fakta empiris di lapangan menunjukkan bahwa hakim cenderung menjatuhkan sanksi pidana penjara pada pecandu. ${ }^{3}$ Akibatnya pecandu narkotika mendekam di Lembaga Pemasyarakatan (Lapas) tanpa diberi kesempatan untuk direhabilitasi, sehingga pelaksanaan rehabilitasi belum berjalan secara maksimal. Saat ini jumlah warga binaan pemasyarakatan di Indonesia mencapai 23.779 orang yang merupakan penyalahgunaan narkoba yang menjalani pidana penjara di lembaga pemasyarakatan. ${ }^{4}$

Kondisi ini mengakibatkan timbulnya masalah lain seperti beban lembaga pemasyarakatan selanjutnya disingkat Lapas menjadi over capacity, ${ }^{5}$ Lapas justru menjadi tempat aman bagi penyalahgunaan narkoba dan munculnya tindak pidana lain yang diakibatkan oleh penyalahgunaan narkoba di dalam Lapas, selain itu peredaran narkoba juga marak terjadi di Lapas bahkan beberapa kali ditemukan produksi narkoba di dalam Lapas.

Dengan mencermati situasi semacam ini, tentu akan berujung pada tidak selesainya persoalan narkoba, karena ini sama artinya dengan memindahkan pecandu ke dalam tembok penjara tanpa ada upaya untuk disembuhkan, bahkan dapat menjerumuskan mereka ke dalam peredaran gelap narkotika. Pada dasarnya pecandu narkoba memiliki sifat adiksi dengan tingkat relaps yang tinggi, sehingga tidak dapat pulih dengan sendirinya. Mereka perlu dibantu untuk disembuhkan.

Oleh karena itu harus ada paradigma baru dalam penanganan pecandu narkoba. Dalam menangani pecandu narkoba, aparat penegak hukum harus berorientasi kepada sanksi tindakan berupa rehabilitasi demi menyelamatkan masa depan mereka. Untuk dapat memfungsikan peran

Redaktur Harian Metro Baru, "BNN Tangani 18 Ribu Pengguna Narkoba", http://metrobali.com/2014/08/21/2014-bnn-tangani-18-ribupengguna-narkoba/, diakses 1 September 2014.

Universitas Gadjah Mada memiliki UP2N (Unit Pencegahan Penyalahgunaan Narkoba) yang didirikan pada tahun 2004 dan berada di bawah Direktorat Kemahasiswaan Universitas Gadjah Mada.

Modul Kegiatan Survei Nasional Penyalahgunaan Narkoba di Indonesia (Kerugian Sosial Ekonomi) di 17 Provinsi Tahun 2014 , BNN dan Pusat Penelitian Kesehatan Universitas Indonesia.

BNN, "Deskriminalisasi Penyalahgunaan Narkotika dalam Konstruksi Hukum Positif di Indonesia", http://dedihumas.bnn.go.id/read/section/ berita/2013/10/29/791/dekriminalisasi-penyalah-guna-narkotika-dalam-konstruksi-hukum-positif-di-indonesia, diakses 1 September 2014.

Ahmad Romadoni, "Napi Dibekuk Saat Memproduksi Narkoba di Lapas Cipinang”, http://news.liputan6.com/read/819336/2-napi-dibekuksaat-memproduksi-narkoba-di-lapas-cipinang, diakses 1 September 2014. 
hakim dalam memutus atau menetapkan rehabilitasi perlu dukungan dari aparat penegak hukum yang lain. Tentu hal ini harus berlandaskan pada adanya pemahaman dan kesepakatan bersama bahwa penyalahgunaan narkoba adalah masalah serius bangsa dan musuh bangsa. Pemerintah dan aparat penegak hukum wajib bersatu padu menyamakan visi dan misi untuk menanggulangi penyalahgunaan narkoba demi mewujudkan cita-cita luhur bangsa menjadikan generasi bangsa yang sehat.

Pemahaman dan kesepakatan dari pemerintah dan aparat penegak hukum ini kemudian diwujudkan melalui Peraturan Bersama Ketua Mahkamah Agung Republik Indonesia, Menteri Hukum dan Hak Asasi Manusia Republik Indonesia, Menteri Kesehatan Republik Indonesia, Menteri Sosial Republik Indonesia, Jaksa Agung Republik Indonesia, Kepala Kepolisian Republik Indonesia, Kepala Badan Narkotika Nasional Republik Indonesia Nomor: 01/ PB/MA/III/2014, Nomor: 03 Tahun 2014, Nomor: 11 Tahun 2014, Nomor: 03 Tahun 2014, Nomor: PER005/A/JA/03/2014, Nomor: 1 Tahun 2014, Nomor: PERBER/01/III/2014/BNN tentang Penanganan Pecandu Narkotika dan Korban Penyalahgunaan Narkotika ke dalam Lembaga Rehabilitasi, yang untuk penyebutan selanjutnya disingkat Peraturan Bersama. Dengan demikian pecandu narkoba tidak lagi bermuara pada sanksi pidana penjara melainkan bermuara di tempat rehabilitasi, karena sanksi bagi pecandu disepakati berupa rehabilitasi.

Berdasar Peraturan Bersama tersebut dibentuk tim assessment terpadu yang berkedudukan di tingkat pusat, tingkat provinsi, tingkat kabupaten/ kota terdiri dari tim dokter dan tim hukum. Tim tersebut kemudian melaksanakan analisis hukum, analisis medis dan analisis psikososial serta membuat rencana rehabilitasi yang memuat berapa lama rehabilitasi diperlukan. Hasil assessment tersebut sebagai kelengkapan berkas perkara berfungsi sebagai keterangan seperti visum et repertum. Dibentuknya Peraturan Bersama ini antara lain bertujuan untuk menjadi pedoman teknis dalam penanganan pecandu narkotika sebagai tersangka, terdakwa, atau narapidana dalam menjalani rehabilitasi medis dan/atau rehabilitasi sosial. Selain bertujuan pula agar proses rehabilitasi medis dan rehabilitasi sosial di tingkat penyidikan, penuntutan, serta persidangan dapat terlaksana secara sinergis dan terpadu.

Pelaksanaan Peraturan Bersama ini sendiri akan dilakukan secara bertahap. Sebagai tahap awal, pilot project dilakukan di 16 kota dan kabupaten yakni Kota Batam, Kota Jakarta Timur, Kota Jakarta Selatan, Kabupaten Bogor, Kota Tangerang Selatan, Kota Semarang, Kota Surabaya, Kota Makassar, Kabupaten Maros, Kota Samarinda, Kota Balikpapan, Kota Padang, Kabupaten Sleman, Kota Pontianak, Kota Banjar Baru, dan Kota Mataram. ${ }^{6}$ Pemilihan kota dan kabupaten tersebut berdasar kesiapan infrastruktur seperti pusat rehabilitasi.

Para pecandu narkoba yang tertangkap aparat penegak hukum mulai Selasa, 26 Agustus 2014 tidak lagi dipidana penjara karena setelah melalui proses assessment, para pecandu narkoba akan bermuara di pusat rehabilitasi. Menurut Menteri Hukum dan Hak Asasi Manusia Amir Syamsuddin, ${ }^{7}$ adanya pilot project ini diharapkan dapat menjadi inspirasi bagi daerah lainnya tentang bagaimana penanganan penyalahgunaan narkoba secara proporsional dan profesional. Seluruh konsep mengenai penanganan pecandu narkoba sudah tertuang dengan jelas dalam berbagai aturan. Saat ini, yang diperlukan adalah implementasi dari para penegak hukum untuk dapat mengambil pilihan yang lebih humanis. Semua kembali pada orientasi penegak hukum itu sendiri. Pilihan-pilihan yang lebih baik inilah yang pada faktanya akan menjadi investasi untuk masa depan bangsa. Dengan demikian dapat dipilah mana pelaku tindak pidana narkoba yang pantas masuk ke dalam jeruji besi dan pecandu yang seharusnya

Redaktur Harian Suara Pembaruan, "Mulai Hari Ini Pecandu Narkoba yang Tertangkap Akan Direhabilitasi”, http://www.suarapembaruan. com/home/mulai-hari-ini-pecandu-narkoba-yang-tertangkap-akan-Direhabilitasi/63141, diakses 1 September 2014.

Fana Suparman, "Mulai Hari Ini Pecandu Narkoba yang Tertangkap Akan Direhabilitasi", http://www.beritasatu.com/hukum/205397-mulaihari-ini-pecandu-narkoba-yang-tertangkap-akan-direhabilitasi.html, diakses 2 September 2014. 
dipulihkan di pusat rehabilitasi.

Berdasarkan latar belakang sebagaimana diuraikan di atas, peneliti tertarik untuk mengkaji lebih dalam mengenai pelaksanaan pilot project dari Peraturan Bersama ini khususnya pada tahap penyidikan. Penelitian ini membatasi pembahasan pada pecandu narkotika dan bukan pada korban penyalahgunaan narkotika. Sehubungan dengan hal tersebut, maka permasalahan yang akan diteliti yaitu: Pertama, bagaimana tindakan penyidik terhadap pecandu narkotika pasca berlakunya Peraturan Bersama? Kedua, bagaimana koordinasi antara penyidik dengan lembaga rehabilitasi medis dan rehabilitasi sosial terhadap pecandu narkotika pasca berlakunya Peraturan Bersama?

\section{B. Metode Penelitian}

Penelitian ini merupakan penelitian normatif empiris. ${ }^{8}$ Dilihat dari sifatnya, penelitian hukum ini merupakan penelitian hukum deskriptif. ${ }^{9}$ Bahan atau materi penelitian meliputi data sekunder yang diperoleh dari penelitian pustaka berupa dan berupa bahan hukum primer, bahan hukum sekunder maupun bahan hukum tersier, sedangkan data primer diperoleh dari penelitian lapangan. Analisis data dilakukan secara deskriptif kualitatif dengan mengkuantifikasi data-data yang ada.

\section{Hasil Penelitian dan Pembahasan}

1. Tindakan Penyidik terhadap Pecandu Narkotika Pasca Berlakunya Peraturan Bersama

Pada dasarnya perbuatan menggunakan dan menyalahgunakan narkotika merupakan satu perbuatan pidana, sehingga terhadap pelaku sudah seharusnya dilakukan proses hukum sebagaimana layaknya penegakan hukum terhadap perkara pidana lainnya. Namun untuk saat ini penegakan hukum terhadap pecandu tidak selalu menggunakan sarana penal, karena adanya keharusan rehabilitasi bagi pecandu yang melaporkan diri pada instansi tertentu penerima wajib lapor, sebagaimana ditentukan dalam Pasal 54 Undang-Undang Nomor 35 Tahun 2009 tentang Narkotika.

Menurut Mudzakir, ${ }^{10}$ pergeseran bentuk pemidanaan dari hukuman badan menjadi hukuman tindakan merupakan proses depenalisasi. Depenalisasi terjadi karena adanya perkembangan atau pergeseran nilai hukum dalam kehidupan masyarakat yang mempengaruhi perkembangan nilai hukum pada norma hukum pidana. Perbuatan tersebut tetap merupakan perbuatan yang tercela, tetapi tidak pantas dikenai sanksi pidana yang berat, lebih tepat dikenai sanksi pidana ringan atau tindakan.

Dalam Peraturan Pemerintah Nomor 25 Tahun 2011 tentang Pelaksanaan Wajib lapor bagi Pecandu Narkotika, pada Pasal 13 ayat (3) disebutkan bahwa pecandu yang sedang menjalani proses peradilan dapat ditempatkan dalam lembaga rehabilitasi medis dan/atau rehabilitasi sosial. Lebih lanjut dalam ayat (4) ditegaskan bahwa penentuan rehabilitasi pecandu menjadi kewenangan penyidik, penuntut umum dan hakim setelah mendapat rekomendasi dari tim dokter.

Dengan adanya Peraturan Bersama, maka proses penyidikan terhadap pecandu maupun penyalahgunaan narkotika mengalami perubahan. Bagi pecandu dan penyalahgunaan narkotika yang ditangkap maupun tertangkap tangan, maka akan dilakukan assessment oleh tim assessment terpadu yang terdiri dari unsur tim dokter yang terdiri dari dokter dan psikolog, serta tim hukum yang terdiri dari unsur Polri, BNN, Kejaksaan dan Kemenkumham. Adapun tugas dari tim assessment terpadu yaitu untuk menghentikan peredaran gelap narkotika dan penyalahgunaan narkotika serta melakukan assessment dan analisa medis, psikososial dan merekomendasi rencana terapi dan rehabilitasi pecandu dan penyalahgunaan narkotika.

\footnotetext{
Ronny Hinitijo Soemitro, 1994, Metodologi Penelitian Hukum dan Jurimetri, Ghalia Indonesia, Jakarta, hlm. 52. Soerjono Soekanto, 1984, Pengantar Penelitian Hukum, UI-Press, Jakarta, hlm. 10.

Mudzakir, "Dekriminalisasi Pecandu Narkotika", Makalah, Focus Group Discussion Badan Narkotika Nasional bekerjasama dengan Fakultas Hukum Universitas Gadjah Mada, Yogyakarta, 10 Oktober 2014.
} 
Tim assessment terpadu juga mempunyai beberapa kewenangan yang mencakup beberapa hal seperti permintaan penyidik untuk melakukan analisis peran seorang yang ditangkap atau tertangkap tangan; peran seseorang sebagai korban penyalahgunaan, pecandu atau pengedar narkotika; menentukan kriteria tingkat keparahan pengguna narkotika sesuai dengan jenis kandungan yang dikonsumsi; merekomendasi rencana terapi dan rehabilitasi terhadap pecandu dan korban penyalahgunaan narkotika.

Dalam praktek, ada beberapa pecandu yang tertangkap baik oleh penyidik Polri, Penyidik PPNS maupun BNN. Namun tindakan para penyidik terhadap pecandu tersebut tidak selalu sama. Sebenarnya dengan adanya undang-undang narkotika, peraturan pemerintah dan peraturan bersama, sudah ada ketentuan yang seragam untuk penindakan terhadap pecandu. ${ }^{11}$

\section{a. Tindakan Penyidik Polres Sleman Pasca Berlakunya Peraturan Ber- sama}

Berdasarkan data yang diperoleh dari Polres Sleman, jumlah tersangka tindak pidana narkoba sejak Bulan Januari hingga November Tahun 2014 sebanyak 57 (lima puluh tujuh) orang, 3 (tiga) orang diantaranya merupakan tersangka pecandu narkotika yang ditangkap sejak dicanangkannya Peraturan Bersama pada Bulan Agustus 2014. ${ }^{12}$ Dalam hal ada pecandu narkotika yang melaporkan diri secara sukarela ke Polres Sleman, maka akan diarahkan ke IPWL yang ditunjuk oleh pemerintah untuk dilakukan assessment guna menentukan dapat atau tidaknya dilakukan

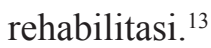

Dalamjangka waktu 1x24 jam Penyidik Polres Sleman melakukan pemeriksaan atau wawancara dengan tersangka. ${ }^{14}$ Apabila mereka terindikasi sebagai pecandu, maka dilakukan tindakan assessment. ${ }^{15}$ Untuk pemeriksaan kesehatan dilakukan oleh dokter dari Rumah Sakit Bhayangkara dan untuk pemeriksaan psikologi oleh Rumah Sakit Grhasia. ${ }^{16}$ Selanjutnya, dari hasil assessment mereka diberi rekomendasi untuk direhabilitasi di Panti Sosial Pamardi Putra, selanjutnya disingkat PSPP. ${ }^{17}$

Tindakan penyidik yang memberi kesempatan untuk merehabilitasi pecandu didasarkan pada Peraturan Bersama Pasal 3 ayat (1) dan Pasal 4 ayat (1), ayat (2), serta ayat (3) serta Surat Telegram Kepala Kepolisian Negara Republik Indonesia (Kapolri) Nomor: STR/701/VII/2014 Tanggal 22 Agustus 2014. Dalam hal ini Penyidik Polres Sleman hanya memberi kesempatan rehabilitasi pada tersangka pecandu narkotika di Kabupaten Sleman yang memiliki barang bukti dan batasan pemakaian paling banyak 5 gram. ${ }^{18}$ Apabila barang bukti yang dibawa tersangka lebih dari 5 gram, penyidik Polres Sleman tidak memberi rekomendasi untuk dilakukan tes assessment.${ }^{19}$ Ketentuan ini mengacu pada Surat Edaran Mahkamah Agung Republik Indonesia Nomor 04 Tahun 2010 tentang Penempatan Penyalahgunaan, Korban penyalahgunaan dan Pecandu Narkotika ke dalam Lembaga Rehabilitasi Medis dan Rehabilitasi Sosial (selanjutnya disebut SEMA Nomor 4 Tahun 2010). Sebenarnya SEMA tersebut ditujukan sebagai petunjuk pada hakim ketika akan menjatuhkan putusan berupa tindakan rehabilitasi bagi pecandu, korban yang tertangkap tangan maupun dengan barang bukti pemakaian dalam satu hari paling

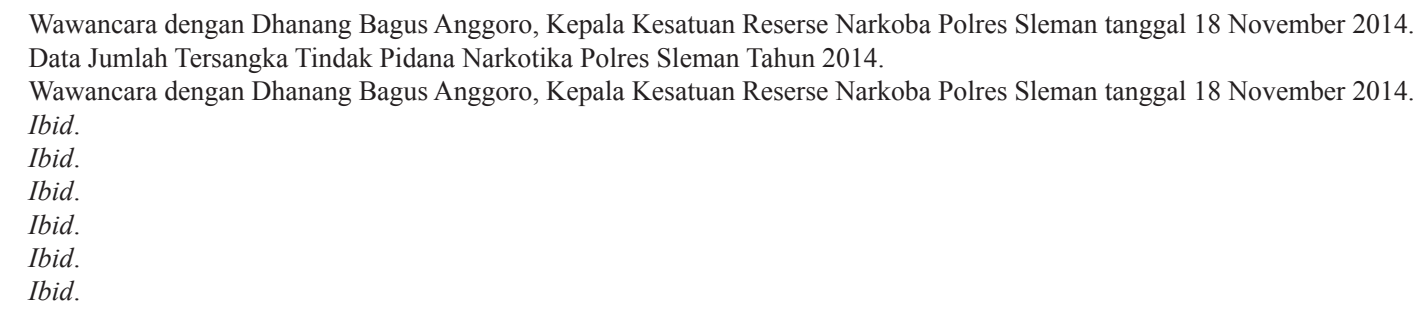


banyak 5 gram. Tindakan yang dilakukan oleh penyidik Polres Sleman untuk tidak memberi rekomendasi assessment terhadap pecandu dengan bukti pemakaian lebih dari 5 gram sehari sehingga tidak dapat dilakukan rehabilitasi, seperti yang ditentukan dalam Pasal 4 ayat (4) dapat dikatakan sebagai suatu tindakan hati-hati.

Dalam Surat Telegram Kapolri Nomor 701 Tahun 2014, ditentukan bahwa permohonan rehabilitasi bagi pecandu yang berstatus tersangka harus diajukan secara tertulis oleh tersangka atau pihak keluarga atau penasehat hukum kepada penyidik. Namun demikian menurut keterangan Polres Sleman, tindakan penyidik untuk melakukan rehabilitasi terhadap para pecandu tersebut berdasarkan inisiatif dari penyidik, sementara permohonan dari tersangka atau kuasa hukum belum pernah ada. ${ }^{20}$ Sebenarnya apa yang dilakukan oleh penyidik narkoba Polres Sleman dengan berinisiatif untuk melakukan tindakan rehabilitasi pada pecandu narkotika sudah sesuai amanat dari Peraturan Pemerintah Nomor 25 Tahun 2011 dan Peraturan Bersama sehingga tidak perlu menunggu pemohonan dari tersangka karena belum tentu aturan-aturan yang memberi kesempatan rehabilitasi bagi pecandu tersebut diketahui oleh masyarakat.

Assessment hanya dilakukan oleh penyidik, BNN Provinsi dan dokter saja. ${ }^{21}$ Untuk instansi lain seperti Kejaksaan Negeri Sleman serta Kementerian Hukum dan HAM hanya diberi laporan mengenai tindakan yang sudah dilakukan oleh penyidik. ${ }^{22}$ Sedangkan BNN Kabupaten Sleman dilibatkan dalam assessment ini karena untuk perkara-perkara narkotika, penyidik Polri harus melakukan koordinasi dengan BNN setempat. ${ }^{23}$ Dari hasil assessment tersebut, kemudian tersangka direhabilitasi dengan ditempatkan di PSPP Sleman yang ditunjuk oleh pemerintah sebagai salah satu pilot project pelaksanaan rehabilitasi. ${ }^{24}$ Rehabilitasi yang dilakukan lebih banyak berupa rehabilitasi sosial, namun untuk terapi medis tetap diberikan. ${ }^{25}$ Tindakan rehabilitasi yang dilakukan oleh PSPP ini bukan termasuk bentuk penahanan oleh penyidik, karena penyidik sudah menyerahkan sepenuhnya tanggungjawab tersangka termasuk keamanan kepada lembaga rehabilitasi. ${ }^{26}$ Dalam hal ini PSPP berkoordinasi dengan Polsek setempat. ${ }^{27}$ Penyidik Polisi Resor Sleman hanya memberikan kesempatan rehabilitasi pada pecandu saja. ${ }^{28}$ Sedangkan pecandu yang juga sebagai pengedar tidak direhabilitasi karena dikhawatirkan mereka akan mempengaruhi tersangka maupun narapidana lainnya. ${ }^{29}$

\section{b. Tindakan Penyidik BNN Pasca Berlakunya Peraturan Bersama \\ BNN Kabupaten Sleman hingga saat} ini belum mempunyai penyidik, sehingga apabila ada pecandu, korban penyalahgunaan narkotika maupun pengedar narkotika yang ditangkap maupun tertangkap tangan, penyidikan dilakukan oleh penyidik polisi, dalam hal ini penyidik dari Unit Narkoba Polres Sleman yang kemudian akan dilaporkan pada penyidik BNNP DIY.

Pada Bulan Agustus Tahun 2014 BNN mencanangkan Peraturan Bersama yang merupakan bentuk keprihatinan BNN 
atas tindakan yang dilakukan penyidik Polri terhadap pecandu, korban penyalahgunaan narkotika. Selama ini tindakan yang terjadi dalam penanganan kasus-kasus tersebut, hampir tidak pernah dilakukan tindakan rehabilitasi. Amanah dari Undang-Undang Nomor 35 Tahun 2009 tentang Narkotika dan Peraturan Pemerintah Nomor 25 Tahun 2011 yang memberi kemungkinan pecandu, korban yang ditangkap atau tertangkap tangan untuk bisa diberi kesempatan direhabilitasi, hanya dilakukan pada orangorang tertentu atau hanya pada pecandu yang melaporkan diri. ${ }^{30}$ Sebenarnya peraturan tersebut mengharuskan rehabilitasi bagi pecandu untuk dapat direhabilitasi baik secara medis dan atau sosial. Kata "dapat" tersebut merupakan pilihan bagi penegak hukum untuk merehabilitasi pecandu, namun dalam praktek, penegak hukum lebih sering tidak melakukan upaya rehabilitasi pada pecandu. ${ }^{31}$ Hal ini berimplikasi masih banyaknya pecandu narkotika yang berada di Rumah Tahanan dan Lembaga Pemasyarakatan tanpa memperoleh penyembuhan tepat melalui rehabilitasi. $^{32}$

Sejak diberlakukan Peraturan Bersama, penyidik BNNP DIY pernah menangani kasus narkotika, ketika dilakukan razia di rumah hiburan dan kafe. ${ }^{33}$ Pada saat itu penyidik menangkap 2 (dua) remaja putri yang merupakan saudara kembar yang bekerja di sebuah kafe. Kemudian penyidik BNNP bekerjasama dengan dokter dari RS Grhasia untuk melakukan assessment. Dari hasil assessment, keduanya dinyatakan sebagai pecandu tahap awal, sehingga kemudian terhadap keduanya diberi kesempatan untuk direhabilitasi dengan cara rawat jalan.
Pelaksanaan rehabilitasi dilakukan di RS Grhasia. Sebenarnya RS Grhasia bukan tempat yang ditunjuk sebagai salah satu pilot project, namun tempat tersebut mendapat rekomendasi pemerintah sebagai salah satu rumah sakit swasta untuk tempat rehabilitasi pecandu narkotika. Selama jangka waktu 3 (tiga) bulan proses rehabilitasi tersebut harus dijalani, dan mereka pada saat-saat tertentu harus datang ke BNNP maupun RS Grhasia. Lamanya jangka waktu rehabilitasi ini disesuaikan dengan pelaksanaan pilot project Peraturan Bersama yang berlangsung sejak bulan Agustus hingga Desember 2014.

\section{c. Tindakan Penyidik PPNS Pasca Berlakunya Peraturan Bersama \\ Dalam Pasal 6 ayat (1) huruf b KUHAP} diatur mengenai pejabat penyidik lainnya selain penyidik Polri, yaitu penyidik pejabat pegawai negeri sipil (PPNS). Pada Dinas Kesehatan Kabupaten Sleman, diperoleh fakta bahwa dinas tersebut sampai saat ini belum dapat melaksanakan fungsi penyidikan sebagaimana ditentukan dalam Pasal 82 Undang-Undang Nomor 35 Tahun 2009 tentang Narkotika. ${ }^{34}$ Secara kelembagaan, Dinas Kesehatan Kabupaten Sleman memiliki 4 (empat) bidang kelompok jabatan fungsional ${ }^{35}$ yang keempatnya sama sekali tidak melakukan fungsi represif penanganan kasus narkotika.

Menurut Kepala Bidang Kesehatan Khusus Dinas Kesehatan Kabupaten Sleman, ${ }^{36}$ ketiadaan fungsi penyidikan disebabkan karena Dinas Kesehatan memiliki masalah dengan sumber daya manusia dan sumber dana. Sumber daya manusia yang dimaksud berkaitan dengan ketiadaan satupun penyidik PPNS terlatih

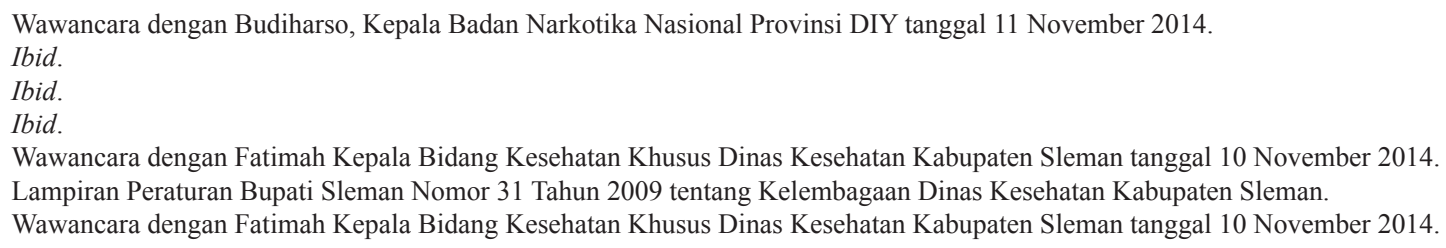


yang diberikan oleh Kabupaten Sleman, sedangkan permasalahan sumber dana yang dimaksud berkaitan dengan ketiadaan pos anggaran untuk penyidikan kasus narkotika dalam rencana anggaran tahunan Dinas Kesehatan Kabupaten Sleman. Oleh karena itu, pasca Peraturan Bersama diterbitkan, bagi Dinas Kesehatan memang tidak terdapat banyak perubahan signifikan.

Ketiadaan penyidik PPNS pada Dinas Kesehatan Kabupaten Sleman, dapat teratasi dengan adanya penyidik PPNS di lingkungan instansi lain yang ada di wilayah hukum DIY, seperti penyidik PPNS dari Kantor Bea Cukai, Kantor Imigrasi. Dalam hal penyidikan dilakukan oleh penyidik PPNS, maka ketika memulai penyidikan, harus melaporkan kepada penyidik Polri. Maksud dari pelaporan ini supaya Penyidik Polri memberikan petunjuk dan bantuan terhadap penyidik PPNS. Apabila penyidikan telah selesai dilakukan oleh Penyidik PPNS, berkas penyidikan kemudian diserahkan kepada penyidik Polri.

\section{Koordinasi antara Penyidik dengan Lembaga Rehabilitasi Medis dan Rehabilitasi Sosial terhadap Pecandu Parkotika Pasca Berlakunya Peraturan Bersama}

Salah satu tahap dalam sistem peradilan pidana adalah tahap penyidikan. Kewenangan penyidikan terhadap penyalahgunaan dan peredaran gelap narkotika dan prekursor narkotika dimiliki oleh Penyidik Polri dan Penyidik BNN. ${ }^{37}$ Sedangkan Penyidik PPNS tertentu sebagaimana dimaksud dalam Undang-Undang tentang Hukum Acara Pidana berwenang melakukan penyidikan terhadap tindak pidana penyalahgunaan narkotika dan prekursor narkotika. ${ }^{38}$ Penyidik PPNS tertentu tersebut dapat berasal dari lingkungan kementerian atau lembaga pemerintah non kementerian yang lingkup tugas dan tanggung jawabnya di bidang narkotika dan prekursor narkotika yaitu Kementerian Kesehatan, Kementerian Keuangan dalam hal ini Direktorat Jenderal Bea dan Cukai dan Badan Pengawas Obat dan Makanan.

Berdasarkan hasil penelitian di Kabupaten Sleman, penyidik yang menangani tindak pidana narkotika adalah penyidik Polri dan penyidik BNN Kabupaten Sleman. Penyidik PPNS yang salah satunya dapat berasal dari Kementerian Kesehatan dalam hal ini adalah Dinas Kesehatan Kabupaten Sleman belum pernah melaksanakan fungsi penyidikan sebagaimana ditegaskan dalam Undang-Undang Nomor 35 Tahun 2009 tentang Narkotika tersebut. Pada prinsipnya penanganan terhadap pecandu narkotika pasca berlakunya Peraturan Bersama dilakukan dengan 2 (dua) cara yaitu: pecandu secara sukarela melaporkan diri ke IPWL dan melalui penegakan hukum.

\section{a. Pecandu secara Sukarela Melapor- kan Diri ke IPWL}

Telah ditegaskan dalam Pasal 54 Undang-Undang Nomor 35 Tahun 2009 tentang Narkotika bahwa pecandu narkotika wajib menjalani rehabilitasi medis dan rehabilitasi sosial. Berdasarkan ketentuan ini maka orang tua atau wali dari pecandu narkotika yang belum cukup umur wajib melaporkan kepada pusat kesehatan masyarakat, rumah sakit, dan/atau lembaga rehabilitasi medis dan rehabilitasi sosial yang ditunjuk oleh pemerintah untuk mendapatkan pengobatan dan/atau perawatan melalui rehabilitasi medis dan rehabilitasi sosial. ${ }^{39}$ Di samping itu bagi pecandu narkotika yang sudah cukup umur juga wajib melaporkan diri atau dilaporkan oleh keluarganya

37 Pasal 81 Undang-Undang Nomor 35 Tahun 2009 tentang Narkotika (Lembaran Negara Republik Indonesia Tahun 2009 Nomor 143 , Tambahan Lembaran Negara Republik Indonesia Nomor 5062).

38 Pasal 82 ayat (1) Undang-Undang Nomor 35 Tahun 2009 tentang Narkotika (Lembaran Negara Republik Indonesia Tahun 2009 Nomor 143, Tambahan Lembaran Negara Republik Indonesia Nomor 5062).

39 Pasal 55 ayat (1) Undang-Undang Nomor 35 Tahun 2009 tentang Narkotika (Lembaran Negara Tahun 2009 Nomor 143, Tambahan Lembaran Negara Republik Indonesia Nomor 5062). 
kepada pusat kesehatan masyarakat, rumah sakit, dan/atau lembaga rehabilitasi medis dan rehabilitasi sosial yang ditunjuk oleh pemerintah untuk mendapatkan pengobatan dan/atau perawatan melalui rehabilitasi medis dan rehabilitasi sosial. ${ }^{40}$ Oleh karena itu diharapkan para pecandu narkotika yang saat ini "bersembunyi" dapat keluar dan tidak perlu takut akan ditangkap dan dikenakan pidana penjara, untuk melaporkan diri secara sukarela kepada IPWL agar mendapatkan perawatan. IPWL adalah pusat kesehatan masyarakat, rumah sakit, dan/atau lembaga rehabilitasi medis dan lembaga rehabilitasi sosial yang ditunjuk oleh pemerintah. ${ }^{41}$

Pecandu narkotika atau keluarganya juga dapat melaporkan diri secara suka rela selain pada IPWL adalah melalui Polri dan BNN. ${ }^{42}$ Selanjutnya petugas di Polri atau BNN yang menerima laporan meneruskannya kepada IPWL. IPWL wajib melakukan assessment meliputi aspek medis dan aspek sosial terhadap pecandu narkotika untuk mengetahui kondisi pecandu narkotika. ${ }^{43}$ Assessment dilakukan dengan cara wawancara, observasi, serta pemeriksaan fisik dan psikis terhadap pecandu narkotika. ${ }^{44}$ Wawancara meliputi riwayat kesehatan, riwayat penggunaan narkotika, riwayat pengobatan dan perawatan, riwayat keterlibatan pada tindak kriminalitas, riwayat psikiatris, serta riwayat keluarga dan sosial pecandu narkotika. ${ }^{45}$ Observasi meliputi observasi atas perilaku pecandu narkotika. ${ }^{46}$ Hasil assessment dicatat pada rekam medis atau catatan perubahan perilaku pecandu narkotika dan bersifat rahasia. ${ }^{47}$ Hasil assessment merupakan dasar dalam rencana rehabilitasi terhadap pecandu narkotika yang bersangkutan ${ }^{48}$ dan rencana rehabilitasi harus disepakati oleh pecandu narkotika, orangtua, wali, atau keluarga pecandu narkotika dan pimpinan IPWL. ${ }^{49}$

Pecandu narkotika yang telah melaporkan diri atau dilaporkan kepada IPWL diberi kartu lapor diri setelah menjalani assessment.$^{50}$ Kartu lapor diri tersebut berlaku untuk 2 (dua) kali masa perawatan. ${ }^{51}$ Masa perawatan adalah suatu layanan program rencana terapi dibuat berdasarkan hasil assessment yang komprehensif yang sesuai dengan kondisi klien dengan jenis gangguan penggunaan narkotika dan kebutuhan individu/klien/pecandu narkotika dengan program yang dijalankan mengikuti program yang tersedia di layanan, dengan waktu

40 Pasal 55 ayat (2) Undang-Undang Nomor 35 Tahun 2009 tentang Narkotika (Lembaran Negara Tahun 2009 Nomor 143, Tambahan Lembaran Negara Republik Indonesia Nomor 5062).

41 Pasal 1 angka 2 Peraturan Pemerintah Nomor 25 Tahun 2011 tentang Pelaksanaan Wajib Lapor Pecandu Narkotika (Lembaran Negara Republik Indonesia Tahun 2011 Nomor 46, Tambahan Lembaran Negara Republik Indonesia Nomor 5211).

42 Penjelasan Pasal 6 ayat (2) Peraturan Pemerintah Nomor 25 Tahun 2011 tentang Pelaksanaan Wajib Lapor Pecandu Narkotika (Lembaran Negara Republik Indonesia Tahun 2011 Nomor 46, Tambahan Lembaran Negara Republik Indonesia Nomor 5211).

43 Pasal 7 ayat (2) Peraturan Pemerintah Nomor 25 Tahun 2011 tentang Pelaksanaan Wajib Lapor Pecandu Narkotika (Lembaran Negara Republik Indonesia Tahun 2011 Nomor 46, Tambahan Lembaran Negara Republik Indonesia Nomor 5211).

44 Pasal 8 ayat (1) Peraturan Pemerintah Nomor 25 Tahun 2011 tentang Pelaksanaan Wajib Lapor Pecandu Narkotika (Lembaran Negara Republik Indonesia Tahun 2011 Nomor 46, Tambahan Lembaran Negara Republik Indonesia Nomor 5211).

45 Pasal 8 ayat (2) Peraturan Pemerintah Nomor 25 Tahun 2011 tentang Pelaksanaan Wajib Lapor Pecandu Narkotika (Lembaran Negara Republik Indonesia Tahun 2011 Nomor 46, Tambahan Lembaran Negara Republik Indonesia Nomor 5211).

46 Pasal 8 ayat (3) Peraturan Pemerintah Nomor 25 Tahun 2011 tentang Pelaksanaan Wajib Lapor Pecandu Narkotika (Lembaran Negara Republik Indonesia Tahun 2011 Nomor 46, Tambahan Lembaran Negara Republik Indonesia Nomor 5211).

47 Pasal 9 ayat (1) Peraturan Pemerintah Nomor 25 Tahun 2011 tentang Pelaksanaan Wajib Lapor Pecandu Narkotika (Lembaran Negara Republik Indonesia Tahun 2011 Nomor 46, Tambahan Lembaran Negara Republik Indonesia Nomor 5211).

48 Pasal 9 ayat (2) Peraturan Pemerintah Nomor 25 Tahun 2011 tentang Pelaksanaan Wajib Lapor Pecandu Narkotika (Lembaran Negara Republik Indonesia Tahun 2011 Nomor 46, Tambahan Lembaran Negara Republik Indonesia Nomor 5211).

49 Pasal 9 ayat (4) Peraturan Pemerintah Nomor 25 Tahun 2011 tentang Pelaksanaan Wajib Lapor Pecandu Narkotika (Lembaran Negara Republik Indonesia Tahun 2011 Nomor 46, Tambahan Lembaran Negara Republik Indonesia Nomor 5211).

50 Pasal 10 ayat (1) Peraturan Pemerintah Nomor 25 Tahun 2011 tentang Pelaksanaan Wajib Lapor Pecandu Narkotika (Lembaran Negara Republik Indonesia Tahun 2011 Nomor 46, Tambahan Lembaran Negara Republik Indonesia Nomor 5211).

51 Pasal 10 ayat (1) Peraturan Pemerintah Nomor 25 Tahun 2011 tentang Pelaksanaan Wajib Lapor Pecandu Narkotika (Lembaran Negara Republik Indonesia Tahun 2011 Nomor 46, Tambahan Lembaran Negara Republik Indonesia Nomor 5211). 
minimal 1 (satu) sampai 6 (enam) bulan sesuai dengan Standar Pelayanan Terapi dan Rehabilitasi Gangguan Penggunaan Narkotika yang ditetapkan Menteri. ${ }^{52}$ Hasil assessment yang komprehensif tersebut meliputi 7 (tujuh) domain utama proses assessment gangguan penggunaan narkotika, yaitu informasi demografis, status medis, status pekerjaan/pendidikan, status penggunaan narkotika, status legal, riwayat keluarga/sosial dan status psikiatri. Standar
Pelayanan Terapi dan Rehabilitasi Gangguan Penggunaan Narkotika, meliputi antara lain: pelayanan detoksifikasi, pelayanan gawat darurat, pelayanan rehabilitasi (melalui model terapi komunitas, model minnesota, model medis, atau model lainnya), pelayanan rawat jalan non rumatan, pelayanan rawat jalan rumatan, dan pelayanan penatalaksanaan dual diagnosis. ${ }^{53}$ Tabel berikut menunjukkan tempat pusat rehabilitasi narkotika di Provinsi DIY.

Tabel 1. Tempat Pusat Rehabilitasi Provinsi DIY

\begin{tabular}{|c|c|c|c|}
\hline No. & Tempat Pusat Rehabilitasi & Pemilik & Ijin \\
\hline 1. & $\begin{array}{l}\text { Lembaga Berita Kitab Wahyu } \\
\text { Internasional }\end{array}$ & $\begin{array}{l}\text { Yayasan Berita Kitab } \\
\text { Wahyu Internasional }\end{array}$ & $\begin{array}{l}\text { Dinsos DIY No. 188/0935/VI/2010 } \\
17 \text { Maret } 2010\end{array}$ \\
\hline 2. & Griya Pemulihan Siloam & $\begin{array}{l}\text { Yayasan Pemulihan } \\
\text { Siloam }\end{array}$ & $\begin{array}{l}\text { IPWL No. 36/Huk/2013 } \\
17 \text { April } 2013\end{array}$ \\
\hline 3. & Rehabilitasi Charis & Yayasan Charis & $\begin{array}{l}\text { IPWL No. 36/Huk/2013 } \\
17 \text { April } 2013\end{array}$ \\
\hline 4. & Rehabilitasi Kunci Yogyakarta & Yayasan Kunci & $\begin{array}{l}\text { IPWL No. 36/Huk/2013 } \\
17 \text { April } 2013\end{array}$ \\
\hline 5. & Pondok Pesantren Al Islamy & Yayasan Al Islamy & $\begin{array}{l}\text { Badan Kerjasama dan Penanaman } \\
\text { Modal No. } 222 / 675 / \text { GR.I/2012 } \\
10 \text { Oktober } 2012\end{array}$ \\
\hline 6. & PSPP & Dinsos Prop DIY & $\begin{array}{l}\text { IPWL No. 36/Huk/2013 } \\
17 \text { April } 2013\end{array}$ \\
\hline 7. & RSUP Dr. Sardjito & Pemerintah & $\begin{array}{l}\text { Skep Dinkes No. 441/10641/III.2 } \\
\text { 16 Desember } 2013\end{array}$ \\
\hline 8. & RS Grhasia & Pemerintah & $\begin{array}{l}\text { Skep Dinkes No. 441/10641/III.2 } \\
\text { 16 Desember } 2013\end{array}$ \\
\hline 9. & RS Bhayangkara & Pemerintah & $\begin{array}{l}\text { Skep Dinkes No. 441/10641/III.2 } \\
16 \text { Desember } 2013\end{array}$ \\
\hline 10. & RSU Kota Yogyakarta & Pemerintah & $\begin{array}{l}\text { Skep Dinkes No. 441/10641/III.2 } \\
\text { 16 Desember } 2013\end{array}$ \\
\hline
\end{tabular}

Sumber: Data Polda Provinsi Daerah Istimewa Yogyakarta Tahun 2014.

Sedangkan untuk data IPWL yang berada di Provinsi DIY berdasarkan data dari Polda DIY Mei 2014 adalah Rumah Sakit Sardjito Yogyakarta, Rumah Sakit Grhasia Yogyakarta, Puskesmas Umbulharjo I, Puskesmas Banguntapan II, Puskesmas Gedong Tengen, PSPP Purwomartani
Kalasan, Rumah Sakit Bhayangkara Polda DIY, Rumah Sakit Kota Yogyakarta, Panti Rehab Charis, Panti Rehab Kunci, Panti Rehab Griya Siloam. ${ }^{54}$ Pendanaan penyelenggaraan ketentuan wajib lapor oleh pemerintah dan pemerintah daerah dibebankan pada Anggaran Pendapatan dan

Pasal 10 ayat (2) Peraturan Pemerintah Nomor 25 Tahun 2011 tentang Pelaksanaan Wajib Lapor Pecandu Narkotika (Lembaran Negara Republik Indonesia Tahun 2011 Nomor 46, Tambahan Lembaran Negara Republik Indonesia Nomor 5211).

54 Data Kepolisian Daerah Istimewa Yogyakarta tentang IPWL di Provinsi Daerah Istimewa Yogyakarta. 
Belanja Negara serta Anggaran Pendapatan dan Belanja Daerah sesuai dengan ketentuan peraturan perundang-undangan. ${ }^{55}$ Pendanaan pelaksanaan rehabilitasi bagi pecandu narkotika yang tidak mampu menjadi tanggung jawab pemerintah dan pemerintah daerah sesuai dengan ketentuan peraturan perundang-undangan. ${ }^{56}$

Pasca berlakunya Peraturan Bersama, berdasar hasil penelitian, belum pernah ada pecandu narkotika yang secara sukarela melaporkan diri melalui Polres Sleman maupun BNN Provinsi DIY. Padahal program wajib lapor secara resmi telah dimulai pada akhir Tahun 2011 sehingga diharapkan dapat lebih banyak menarik kesadaran pecandu dan/atau keluarganya untuk melaporkan diri guna menerima perawatan terkait perilaku ketergantungannya. Dengan semakin meningkatnya jumlah pecandu narkotika yang melaporkan dirinya ke Puskemas, rumah sakit jiwa, dan rumah sakit umum yang ditetapkan sebagai IPWL, maka diharapkan semakin sedikit pecandu yang diputus pidana oleh pengadilan. Namun fakta dalam pelaksanaan, program wajib lapor masih jauh dari yang diharapkan karena belum pernah ada pecandu narkotika yang secara sukarela melaporkan diri.

\section{b. Penanganan terhadap Pecandu Nar- kotika Pasca Berlakunya Peraturan Bersama yang Dilakukan Melalui Penegakan Hukum}

Penegakan hukum memainkan peran yang sangat penting dalam mengintegrasikan dan menyeimbangkan pendekatan kebutuhan (demand) dan peredaran gelap narkotika (supply). Dalam kaitan ini sistem pemidanaan dalam Undang-Undang Nomor 35 Tahun
2009 tentang Narkotika menganut double track system terhadap pecandu narkotika yang mencantumkan sanksi pidana dan sanksi tindakan. Menjatuhkan sanksi tindakan berupa rehabilitasi bagi pecandu narkotika adalah pilihan terbaik yang memiliki nilai tambah karena dapat menurunkan angka prevalensi pecandu narkotika yang merupakan indikator keberhasilan dalam menanggulangi masalah narkotika.

Pecandu Narkotika yang sedang menjalani proses peradilan dapat ditempatkan dalam lembaga rehabilitasi medis dan/ atau rehabilitasi sosial. Penempatan dalam lembaga rehabilitasi medis dan/atau rehabilitasi sosial merupakan kewenangan penyidik, penuntut umum, atau hakim sesuai dengan tingkat pemeriksaan setelah mendapatkan rekomendasi dari tim dokter. ${ }^{57}$ Sehubungan dengan hal tersebut, kerjasama antar penyidik dapat dilakukan untuk mencegah dan memberantas penyalahgunaan dan peredaran gelap narkotika dan prekursor narkotika. Dalam melakukan penyidikan terhadap penyalahgunaan dan peredaran gelap narkotika dan prekursor narkotika, penyidik Polri memberitahukan secara tertulis dimulainya penyidikan kepada penyidik BNN begitu pula sebaliknya. Sedangkan bagi penyidik PPNS tertentu, ketika melakukan penyidikan terhadap penyalahgunaan narkotika dan prekursor narkotika, berkoordinasi dengan penyidik BNN atau penyidik Polri sesuai dengan Undang-Undang tentang Hukum Acara Pidana.

Pada tanggal 26 Agustus 2014 telah dimulai pelaksanaan pilot project Peraturan Bersama di 16 (enam belas) daerah, salah

Pasal 22 ayat (1) Peraturan Pemerintah Nomor 25 Tahun 2011 tentang Pelaksanaan Wajib Lapor Pecandu Narkotika (Lembaran Negara Republik Indonesia Tahun 2011 Nomor 46, Tambahan Lembaran Negara Republik Indonesia Nomor 5211).

56 Pasal 22 ayat (2) Peraturan Pemerintah Nomor 25 Tahun 2011 tentang Pelaksanaan Wajib Lapor Pecandu Narkotika (Lembaran Negara Republik Indonesia Tahun 2011 Nomor 46, Tambahan Lembaran Negara Republik Indonesia Nomor 5211).

57 Pasal 13 ayat (3) dan ayat (4) Peraturan Pemerintah Nomor 25 Tahun 2011 tentang Pelaksanaan Wajib Lapor Bagi Pecandu Narkotika (Lembaran Negara Republik Indonesia Tahun 2011 Nomor 46, Tambahan Lembaran Negara Republik Indonesia Nomor 5211). 
satunya adalah Kabupaten Sleman. Berdasar hasil penelitian, pelaksana fungsi penyidikan dalam penanganan penyalahgunaan dan peredaran gelap narkotika di Kabupaten Sleman hanya dimiliki penyidik Polres Sleman. BNN Kabupaten Sleman sendiri belum mempunyai unit khusus penyidik. Demikian pula untuk kewenangan penanganan penyalahgunaan narkotika tanpa penanganan peredaran gelap narkotika yang dimiliki penyidik PPNS, di Kabupaten Sleman sampai saat ini belum pernah ada penyidik PPNS menangani perkara penyalahgunaan narkotika. Oleh karena itu tidak ada koordinasi antar penyidik dalam penanganan penyalahgunaan maupun peredaran gelap narkotika di Kabupaten Sleman karena yang menjalankan fungsi penyidikan hanya penyidik Polres Sleman.

Fungsi penyidikan memiliki kaitan erat dengan penanganan pecandu narkotika ke dalam lembaga rehabilitasi. Kewenangan penyidik Polri dalam penempatan pecandu narkotika didasarkan pada Surat Telegram Kapolri Nomor STR/701/VIII/2014 yang antara lain menegaskan bahwa pelaksanaan rehabilitasi bagi pecandu narkotika benarbenar didasarkan pada pertimbangan bahwa pelaku adalah pecandu dan bukan didasarkan pada besar kecilnya barang bukti yang disita serta bukan pelaku pengedar atau anggota jaringan peredaran gelap narkotika. Selanjutnya terkait pilot project tempat rehabilitasi pecandu narkotika di Kabupaten Sleman telah ditetapkan di PSPP Sleman. Berdasarkan hasil penelitian di Polres Sleman, jumlah pecandu narkotika yang berstatus tersangka pasca berlakunya Peraturan Bersama sebanyak 3 (tiga) orang dengan latar belakang pekerjaan swasta.

Sehubungan denganhal inipermohonan rehabilitasi bagi pecandu narkotika yang berstatus tersangka harus diajukan secara tertulis oleh pihak keluarga atau penasehat hukumnya kepada penyidik. Dalam proses penyidikan berdasarkan pertimbangan yang layak dan wajar, penyidik dapat menempatkan pecandu narkotika ke tempat rehabilitasi medis dan atau sosial setelah mendapat surat rekomendasi hasil assessment dari tim assessment terpadu. Berdasar hasil penelitian, terhadap 3 (tiga) tersangka pecandu narkotika tersebut dilakukan assessment oleh tim assessment terpadu yang terdiri dari tim dokter yang meliputi dokter dari Rumah Sakit Bhayangkara, dan psikologi dari Rumah Sakit Grhasia; tim hukum yang terdiri dari unsur Polri yakni Polres Sleman, BNN Kabupaten Sleman, Kejaksaan Negeri Sleman dan Kanwil Kementerian Hukum dan HAM DIY. Berdasarkan hasil penelitian, hasil tim assessment terpadu biasanya berpedoman pada hasil pemeriksaan penyidik.

Penempatan tersangka pecandu narkotika ke tempat rehabilitasi medis ditindaklanjuti dengan memberitahukan kepada Ketua Pengadilan Negeri Sleman dengan tembusan disampaikan kepada Kepala Kejaksaan Negeri Sleman. Selama tersangka pecandu narkotika berada di tempat rehabilitasi medis dan atau sosial, maka faktor pengamananmenjaditanggungjawablembaga rehabilitasi dalam hal ini PSPP dan dalam pelaksanaannya berkoordinasi dengan Polsek Kalasan. Seluruh biaya yang ditimbulkan ditanggung oleh BNN. Selanjutnya terkait dengan tempat pelaksanaan rehabilitasi, harus memenuhi standar dari menteri kesehatan bagi rehabilitasi medis dan standar dari menteri sosial bagi rehabilitasi sosial. Rehabilitasi medis maupun rehabilitasi sosial dilaksanakan di fasilitas rehabilitasi medis maupun rehabilitasi sosial yang diselenggarakan oleh pemerintah, pemerintah daerah atau masyarakat.

Fasilitas rehabilitasi medis mempunyai 
kewajiban: ${ }^{58}$ menyelenggarakan rehabilitasi medis sesuai standar profesi, standar pelayanan dan standar prosedur operasional; melaksanakan fungsi sosial; berperan serta dalam jejaring dan melaksanakan fungsi rujukan; melaksanakan serangkaian terapi dan upaya pencegahan penularan penyakit melalui penggunaan narkotika suntik; menyusun standar prosedur operasional penatalaksanaan rehabilitasi sesuai dengan modalitas yang digunakan dengan mengacu pada standar dan pedoman penatalaksanaan medis; melakukan pencatatan dan pelaporan dalam penyelenggaraan rehabilitasi medis. Sedangkan tujuan standar rehabilitasi sosial bagi pecandu narkotika yaitu: ${ }^{59}$ menjadi acuan dalam melaksanakan rehabilitasi sosial bagi pecandu penyalahgunaan narkotika; memberikan perlindungan terhadap pecandu dari kesalahan praktik; memberikan arah dan pedoman kinerja bagi penyelenggara rehabilitasi sosial pecandu penyalahgunaan narkotika; meningkatkan kualitas dan jangkauan pelayanan penyelenggara rehabilitasi sosial pecandu penyalahgunaan narkotika.

Berdasarkan hasil penelitian, Rumah Sakit Grhasia di Pakem Sleman merupakan rumah sakit yang ditunjuk untuk melaksanakan rehabilitasi medis maupun rehabilitasi sosial. Koordinasi antara penyidik Polres Sleman dengan Rumah Sakit Grhasia berlangsung dalam tahap assessment ketika bekerjasama sebagai bagian dari tim assessment terpadu yang menentukan apakah terhadap tersangka perlu dilakukan assessment atau tidak, termasuk untuk mengetahui apakah tersangka merupakan pecandu, bagaimana taraf ketergantungannya sehingga dapat ditentukan rehabilitasi yang tepat bagi yang bersangkutan. Dalam penanganan terhadap 3 (tiga) tersangka pecandu narkotika, sebagai bagian dari tim assessment terpadu, Penyidik Polres Sleman merupakan salah satu unsur dari tim hukum selain BNN Kabupaten Sleman, Kejaksaan Negeri Sleman, dan Kanwil Kemenkumham DIY. Sedangkan Rumah Sakit Grhasia dan Rumah Sakit Bhayangkara menjadi bagian tim dokter. Tim dokter terdiri dari dokter yang berasal dari Rumah Sakit Bhayangkara dan psikolog yang berasal dari Rumah Sakit Grhasia. Pada akhirnya ketika tim assessment terpadu mengarahkan 3 (tiga) tersangka pecandu narkotika tersebut menjalani rehabilitasi, maka para tersangka selanjutnya ditempatkan di PSPP untuk menjalani rehabilitasi baik medis maupun sosial. Selama menjalani masa rehab, pecandu menjadi tanggung jawab lembaga rehabilitasi, dalam hal ini PSPP.

\section{Kesimpulan}

Dari penjabaran di atas, penulisan ini dapat disimpulkan menjadi 2 (dua) kesimpulan yakni: Pertama, tindakan penyidik terhadap pecandu narkotika pasca berlakunya peraturan bersama. Pecandu narkotika yang melaporkan diri secara sukarela, akan diarahkan ke IPWL untuk dilakukan assessment guna menentukan dapat atau tidaknya direhabilitasi. Penyidikan terhadap tersangka pecandu narkotika di Kabupaten Sleman hanya dilakukan oleh Penyidik Polres Sleman karena ketiadaan Penyidik dari Dinas Kesehatan Kabupaten Sleman dan BNN Kabupaten Sleman. Tindakan Penyidik Polres Sleman dalam penanganan terhadap tersangka pecandu yang ditangkap adalah dengan melakukan assessment oleh tim assessment terpadu, terhadap perkara tersebut tetap diproses hukum lebih lanjut. Namun dalam hal tersangka pecandu tersebut merangkap sebagai pengedar, penyidik Polres Sleman tidak akan memberikan kesempatan

Pasal 8 Peraturan Menteri Kesehatan Nomor 2415 TH/MENKES/PER/XII/2011 tentang Rehabilitasi Medis Pecandu, Penyalahgunaan dan Korban Penyalahgunaan Narkotika.

59 Pasal 2 Peraturan Menteri Sosial Nomor 26 Tahun 2012 tentang Standar Rehabilitasi Sosial. 
untuk direhabilitasi. Tindakan ini tidak sesuai dengan ketentuan dalam Peraturan Pemerintah Nomor 25 Tahun 2011 maupun Peraturan Bersama yang memberi kesempatan pecandu sekaligus pengedar dapat direhabilitasi.

Kedua, koordinasi antara penyidik dengan lembaga rehabilitasi medis dan/atau sosial pasca berlakunya peraturan bersama. Pecandu yang secara sukarela melaporkan diri ke Penyidik Polres Sleman akan diarahkan untuk melaporkan diri ke IPWL dalam hal ini PSPP dengan batasan hanya untuk 2 (dua) kali lapor. Tidak ada tuntutan pidana bagi pecandu narkotika yang secara sukarela melaporkan diri ke Polres Sleman. Pasca berlakunya Peraturan Bersama belum ada pecandu narkotika yang secara sukarela melaporkan diri ke Penyidik Polres Sleman. Dalam melakukan assessment, sebagai bagian dari tim assessment terpadu, Penyidik Polres Sleman yang merupakan salah satu unsur dari tim hukum selain BNN Kabupaten Sleman, Kejaksaan Negeri Sleman, serta Kanwil Kemenkumham berkoordinasi dengan Rumah Sakit Bhayangkara dan Rumah Sakit Grhasia yang merupakan tim dokter. Tim dokter terdiri dari dokter yang berasal dari Rumah Sakit Bhayangkara dan psikolog yang berasal dari Rumah Sakit Grhasia.

\section{DAFTAR PUSTAKA}

\section{A. Buku}

BNN dan Pusat Penelitian Kesehatan Universitas Indonesia, 2014, Modul Kegiatan Survei Nasional Penyalahgunaan Narkoba di Indonesia (Kerugian Sosial Ekonomi) di 17 Provinsi Tahun 2014, BNN dan Pusat Penelitian Kesehatan Universitas Indonesia, Jakarta.

Soemitro, Ronny Hinitijo, 1994, Metodologi Penelitian Hukum dan Jurimetri, Ghalia Indonesia, Jakarta.

Soekanto, Soerjono, 1984, Pengantar Penelitian Hukum, UI-Press, Jakarta.

\section{B. Makalah}

Mudzakir, "Dekriminalisasi Pecandu Narkotika", Makalah, Focus Group Discussion Badan Narkotika Nasional bekerjasama dengan Fakultas Hukum Universitas Gadjah Mada, Yogyakarta, 10 Oktober 2014.

\section{Peraturan Perundang-undangan}

Undang-Undang Nomor 35 Tahun 2009 tentang Narkotika (Lembaran Negara Republik Indonesia Tahun 2009 Nomor 143, Tambahan Lembaran Negara Republik Indonesia Nomor 5062).
Peraturan Pemerintah Nomor 25 Tahun 2011 tentang Pelaksanaan Wajib Lapor Pecandu Narkotika (Lembaran Negara Republik Indonesia Tahun 2011 Nomor 46, Tambahan Lembaran Negara Republik Indonesia Nomor 5211).

Peraturan Menteri Kesehatan Nomor 2415 TH/ MENKES/PER/XII/2011 tentang Rehabilitasi Medis Pecandu, Penyalahgunaan dan Korban Penyalahgunaan Narkotika.

Peraturan Menteri Sosial Nomor 26 Tahun 2012 tentang Standar Rehabilitasi Sosial.

Peraturan Bupati Sleman Nomor 31 Tahun 2009 tentang Kelembagaan Dinas Kesehatan Kabupaten Sleman.

\section{Internet}

BNN, "Deskriminalisasi Penyalahgunaan Narkotika dalam Konstruksi Hukum Positif di Indonesia", http://dedihumas.bnn.go.id/ $\mathrm{read} / \mathrm{section} /$ berita/2013/10/29/791/ dekriminalisasi-penyalah-guna-narkotikadalam-konstruksi-hukum-positif-diindonesia, diakses 1 September 2014.

Redaktur Harian Metro Baru, "BNN Tangani 18 Ribu Pengguna Narkoba", http://metrobali. com/2014/08/21/2014-bnn-tangani-18-ribupengguna-narkoba/, diakses 1 September 2014. 
Redaktur Harian Suara Pembaruan, "Mulai Hari Ini Pecandu Narkoba yang Tertangkap Akan Direhabilitasi", http://www.suarapembaruan. com/home/mulai-hari-ini-pecandu-narkobayang-tertangkap-akan-Direhabilitasi/63141, diakses 1 September 2014.

Romadoni, Ahmad, "Napi Dibekuk Saat Memproduksi Narkoba di Lapas Cipinang", http://news.liputan6.com/read/819336/2- napi-dibekuk-saat-memproduksi-narkobadi-lapas-cipinang, diakses 1 September 2014.

Suparman, Fana, "Mulai Hari Ini Pecandu Narkoba yang Tertangkap Akan Direhabilitasi”, http://www.beritasatu.com/hukum/205397mulai-hari-ini-pecandu-narkoba-yangtertangkap-akan-direhabilitasi.html, diakses 2 September 2014. 